\title{
The Narrative Style and Voices in The Waste Land
}

\author{
Feiyue Zhang \\ School of English Studies, Shanghai International Studies University, Shanghai, China
}

\begin{abstract}
The complexity, multiplicity and high degree of polyphony in T. S. Eliot's The Waste Land presents as a significant challenge in terms of interpreting modernist poetry. While expressing concerns about Western civilisation's collapse, as well as modern people's spiritual barrenness, The Waste Land creates a constant tension through its usage of language, narrative structure and various different speech representations. This paper seeks to highlight that as a narrative poem, The Waste Land uses an abundance of narrations, descriptions and dialogues, while exploring how these various elements aid the poet to adopt a modernist narrative style in his poetry.
\end{abstract}

Index Terms-The Waste Land, T. S. Eliot, narrative style, narrative voices

\section{INTRODUCTION}

Widely regarded as "The Poem of the Century", Eliot's The Waste Land expresses concerns about the collapse of Western civilisation, as well as modern people's spiritual barrenness, which may be interpreted from numerous different perspectives. Various critics have adopted social approaches to understand the poem, or, alternatively, have analysed its religious and mythical aspects. However, comparatively little consideration has been given to Eliot's use of different expressions of voice and a changing narrative style, which employs monologues, dialogue and free indirect speech. Studies have noted that the poem's extensive use of literary allusions serves a different functional value to that of other modernist writers (Fornero, 2005; Pondrom, 2005). Critics have also highlighted the aesthetics of fragmentation and juxtaposition, which is closely connected with the poem's symbolic religious meaning (Bruno, 2013; Penda, 2011). Eliot's writing style is representative of modernism, while also deeply influenced by its social background, along with ecological concerns (Penda, 2011; Suarez, 2001). As compared to rhyme, rhythm and images, the analysis of the poem's narrative style presents challenges in terms of its structure and characters. Only a few critics have emphasised how the poem's narrations function with time and space. This paper focuses on T. S. Eliot's employment of the three voices of poetry to depict the narrative style discussed in Shlomith Rimmon-Kenan's book Narrative Fiction: Contemporary Poetics (1983). It draws upon a theoretical framework to interpret The Waste Land's creativity by using literary allusion and the narration of fragmentation with regard to the transformation of the poet and the narrator's voices. In the latter book which presents the collaborative theory of narratology, Shlomith Rimmon-Kenan concludes that the three elements of narrative fiction comprise: "story", "text" and "narration". As the author emphasises, "a succession of events" (p. 3) is one specific feature associated with narrative fiction. This suggests that multiple narratives exist. Accordingly, this analysis classifies The Waste Land as a narrative poem, given that it contains an abundance of narrations, descriptions and dialogues. Furthermore, analysis is undertaken of how these elements aid the poet in adopting a modernist narrative style within the poem.

\section{THE WASTE LAND'S STORY: NARRATIVE AND ANTI-NARRATIVE}

As a poem representative of $20^{\text {th }}$ century modernism, The Waste Land's writing style has powerfully reshaped conceptions of subjectivity, discourse and cultural hierarchy. The seven languages Eliot uses in The Waste Land indicate certain limitations generally in relation to the notion of translatability. Shlomith Rimmon-Kenan (1983) conveys how the story is an abstract form derived from the specific style of the text in question, the language in which it is written, as well as the medium or sign-system. Coyle (2009) stresses that despite The Waste Land comprising narrative fragments, it does not present as a narrative, given the absence of an identifiable locational logic that sustains the poem's "story". Nevertheless, beginning with the story - modernist literature's inner core - as opposed to the text from which meaning may be derived in an abstract manner, the story may be more transferable across mediums, across languages and within the same language. The difficulties which readers continue to struggle with in The Waste Land are more apparent in the epigraph to the poem. Nevertheless, this does not affect the narrative structure, which is dependent to a greater degree on the extensive practice of reading and telling stories. Therefore, readers can still understand Eliot's intended meaning by reading and rereading the poem. Despite its superficial fragmentation, The Waste Land establishes a form of inherent unity. Suarez (2001) uses "gramophone" technology, which seeks to consider how The Waste Land relates to other perspectives such as language, media and culture, which, in turn, influences and reshapes the view portrayed of writing techniques, literary discourse and cultural hierarchy. Narrative refers to the narration of a succession of fictional events, 
rather than merely setting the context as "once upon a time". In contrast to traditional narration, in The Waste Land time past is time present. Therefore, when absorbing the text, which involves an abundance of characters and events drawn from different time and space, readers will need to invest additional effort in order to understand what the story is seeking to convey.

It is difficult to arrange the poem in chronological order as The Waste Land adopts a considerably creative approach when presenting the viewpoints of the characters. Modernist poets were by and large preoccupied with the notion of disorder. One study of the poetics of non-being argues that although Eliot glorifies the concept of disorder, he eventually attempts to make The Waste Land more comprehensible and orderly by providing explanations for his allusions through the use of extensive endnotes (Penda, 2011). In The Waste Land, Eliot juxtaposes distinct perspectives on the same object or situation, a technique that is linked to the aesthetics of fragmentation. Exploring the duality of the nothingness of life, on the one hand, and establishing order and comprehensibility on the other, is reconciled by means of the aesthetic unity of opposites. Penda (2011) scrutinises Eliot's theoretical poetics in The Waste Land in terms of the ideological aspects of the aesthetic of disorderly order. Critics have also re-examined Eliot's allusions to Buddhism in "Fire Sermon", the third section of The Waste Land, thus demonstrating that pervasive Buddhist allusions and influences in the poem exist as "conceptual rhymes" for the emotional, psychological or intellectual experiences Eliot seeks to express poetically (Bruno, 2013). Nevertheless, Eliot concentrates on the word "time" at numerous points throughout the poem with ironic meanings, as with the appearance of the popular song from 1912 "Shakespeherian Rag" (rag time) and the "withered stumps of time", which the woman hung upon the walls (Eliot, 2005, p. 1347). The repetition of "HURRY UP PLEASE ITS TIME" (Eliot, 2005, p. 1348) in the final section of "A Game of Chess" emphasises that it genuinely is the time for Lil to say goodbye to this life. Therefore, the narrative poem connects different times and events with anti-narrative style fragments through the storyteller "I" (Tiresias), thus maintaining the story's existence.

Tiresias' appearance in "The Fire Sermon" suggests an obfuscation of the parameters between the poetic and the prophetic, which drives The Waste Land in its entirety. In Eliot's note, Tiresias is "a mere spectator and not indeed a 'character', is yet the most important personage in the poem, uniting all the rest", and "all the women are one woman, and the two sexes meet in Tiresias. What Tiresias sees, in fact, is the substance of the poem" (Eliot, 2005, p. 1350). The Waste Land's sense of the nothingness of life connects the disorder of its writing style with the implicit notion of establishing order. In the specific narration of the typist and the house agent clerk's love affair, Tiresias plays a role not just as a witness, but rather as a character in the story. The prophet Tiresias, of mixed gender and providing the poem's cohesive voice, purports to have "been there before", having experienced all the awful realities of sex as a form of martyrdom. One is "bored and tired", while the other's "vanity requires no response, and makes a welcome of indifference"; one "bestows one final patronizing kiss", while the other is "hardly aware of her departed lover" (Eliot, 2005, p. 1351). Tiresias "foresuffered" an offensive and perverse sexual encounter, which may further allude to incest or murder, as a darker side of sex. During this section, Tiresias appears to observe and reflect on this modern act of loveless sex-which implicitly parallels Philomela's rape in "A Game of Chess"-with stoic detachment. The few quoted lines within the section "The Fire Sermon", "Well now that's done: and I'm glad it's over" (Eliot, 2005, p. 1351), expresses how exhilaration and passion are entirely removed from the woman's life, thus exemplifying the modern era's recurring apprehension of disappointment. Similar to Tiresias, throughout the poem Eliot shifts between darkness and light, contrasting the darkness in the world with the light surrounding it.

\section{THE WASTE LAND’S TEXT: Two TURnS OF INTRINSIC AND EXTRINSIC STRUCTURE}

There are two pivotal turns in contemporary literary theory. One places an emphasis on the research transforming from author to text; the other is the transition from text to reader. Eliot (1953) delivered a lecture to the National Book League, expounding that three voices are apparent in present poetry: "The first voice is the voice of the poet talking to himself - or to nobody. The second is the voice of the poet addressing an audience, whether large or small. The third is the voice of the poet when he attempts to create a dramatic character speaking in verse" (p. 89). The transition of the critical focus, coupled with the multiplicity of voices used, create greater difficulties for the reader. The Waste Land involves a substantial number of characters, including the Fisher King from The Golden Bough, Countess Marie Larisch and her cousins, Tristan and Isolde in Wagner's opera, Dante in Inferno, Tereus and Philomela in Metamorphoses, Ophelia in Hamlet, among others, thereby providing a range of protagonists from notable literary works and presenting characteristic images of the modern world's social life. These many different characters' appearances are replaced by the personal pronouns "I", "you" and "they". The Waste Land's narrations are presented from various perspectives, with the most recurrent one adopted being first-person narration. Nevertheless, the narrator "I" shifts from different identities to different periods without any clear transitionary stage.

From the perspective of the deep intrinsic structure of The Waste Land, the Holy Grail legend is the concealed symbol functioning throughout the entire poem. The Fisher King, a symbolic figure of infertility who undergoes a great deal of suffering, plays a dominant role throughout the poem. The Fisher King was fishing in the poem twice. In the first instance he is "fishing in the dull canal on a winter evening round behind the gashouse" (Eliot, 2005, p. 1349), while in the other he is "Fishing, with the arid plain behind me" (Eliot, 2005, p. 1356), symbolising human beings in pursuit of salvation, rebirth and eternity. Moreover, driven by the narrative of the troubled body, gender performativity 
has also been acknowledged in the text, where critics have re-examined three crucial emotional scenes in The Waste Land which comprise the hyacinth girl episode in "A Game of Chess" and "What the Thunder Said". This helps the reader to learn about Eliot's own understanding of gender identity (Pondrom, 2005). The first appearance of the hyacinth girl is in "The Burial of the Dead". The speaker's cry of grief, "I could not speak, and my eyes failed, I was neither living nor dead, and I knew nothing, looking into the heart of light, the silence" (Eliot, 2005, p. 1345), reinforces that the tragedy of modern people's love is unavoidable and fatal, without hope, faith and direction. Meanwhile, the disguise of gender identity, such as Madame Sosostris, indicates a vague blurring of sex in modern society. The title of the second chapter of The Waste Land, "A Game of Chess", uses the metaphor of a game of chess to confer order on the fragmented structure of the poem in terms of the problem of the king's intrinsic value. In addition, its myriad of dynamic and symbolic meanings offer a modernist perspective to reshape the literary structure (Fornero, 2005). On the other hand, in terms of visible representation and extrinsic structure, Eliot sets up rich and unique symbolic systems in the poem by introducing the Tarot pack into The Waste Land, orchestrating the seemingly fragmented and chaotic imagery into some kind of order and structure. The symbolic use of Tarot has helped to tie the pieces of the poem together. However, the character, with a multiplicity of perspectives, functions as a poetic construct formulated by the reader from the various indications distinguished throughout the text.

\section{THE WASTE LAND’S NARRATION: SPEECH REPRESENTATION}

No consistent speaker may be identified in The Waste Land. Regular narrative styles are used in abundance throughout the entire five parts, with several narrative techniques employed ranging from traditional narrative structures - for example, descriptive introductions and dialogue with quotation marks - to entirely associative lists of words lacking phrasal syntax, thus presenting readers with gaps to be filled prior to the inference of any meaning. The notion of voice underpins the concept of perspective or point of view, which is a narrative theory. Munganga (2017) explicates how perspective pertains to the manner in which the story's representation is affected by the narrator's position, personality and values, alongside those of the characters and potentially other more hypothetical entities in the story's world. This chapter emphasises not what the poem's characters and words mean, but rather how it means, as well as how the narration facilitates the readers' shaping of their experiences and understandings of the poem.

Shlomith Rimmon-Kenan's (1983) book refers to Helene Cixous' theory, depicting that the "I" is inevitably "more than one, diverse, capable of being all those it will at one time be, a group acting together" (p. 30). The repetition of the narrator's "I" emphasises self-identity and self-consciousness. Accordingly, The Waste Land's narrative voices construct the polyphony with the symbolic characters from various texts, with Eliot applying both direct discourse and free indirect discourse, while altering the voices in the poem. Consequently, this aligns with the characters' mental status and assists readers to comprehend the attitudes and meanings behind the narrator's words. In terms of using quotation marks, direct discourse is a form of monologue or dialogue quotation. The section with hyacinth girl includes a quote by her, alongside a section which appears to be the poem's narrator: "You gave me hyacinths first a year ago"; "They called me the hyacinth girl" (Eliot, 2005, p. 1345). This direct discourse reinforces the impending and fatal tragedy of love. In drafts of The Waste Land, the hyacinth garden is connected to the drowned Phoenician sailor, who appears in "Death by Water" through the genesis of the poem: "Do you know nothing? Do you see nothing? Do you remember Nothing? I remember The hyacinth garden. Those are pearls that were his eyes, yes!" (Eliot, 2005, p. 1347). Moreover, in the final section of "The Burial of the Dead", "I", or the implied author, meets a companion "Stetson" during the battle of Mylae, after which he begins narrating their previous experiences over the course of the war. The name "Stetson" - also a reference to the hat brand, may represent every single man. The narration with quotation marks is in fact a form of direct communication between the narrator and the reader, as well as marking the poet's invitation to unearth feelings from the bottom of the reader's heart. It is "you" and "I" who suffered the battle of Mylae during the First Punic War; when the reader builds a related impression of the Great War, it culminates in the time sequence, the imagery, the actual and the poem itself all closely integrated, suggesting these events would recur and nothing brand new would develop. At the conclusion of the first chapter, the narrator is breaking the fourth wall and speaking directly to the reader: "You! hypocrite lecteur! —mon semblable, —mon frère!” (Eliot, 2005, p. 1346). By quoting Charles Baudelaire's Les Fleurs du mal, Eliot situates the narrator and the reader together with Baudelaire's poetics, implicating the reader in the bored, sordid society.

Eliot situates the speaker's narrative performance and female voices as central to "A Game of Chess". The quote in lines 111-134 depicts a dramatic monologue or one-sided conversation, perhaps the recording of daily exchanges between Eliot and his wife Vivien: "'What are you thinking of? What thinking? What? / 'I never know what you are thinking. Think." (Eliot, 2005, p. 1347). The two personages are dwelling precisely on things that are irrelevant, the "nothings" and banalities of everyday life. The two lines not quoted may be the other response: "I think we are in rat's alley / Where the dead men lost their bones" (Eliot, 2005, p. 1347). The context presents a marriage that has gone terribly stale, while people feeling emptiness and impatience are so close to death. The wife's question, "What is the noise?" provides a play on words to go along with her "husband's" thoughts of death. The repetition of "what" indicates that questions regarding death may have not been requisitely handled. Although the wife is aware that something is going on, she is unable to establish exactly what.

Furthermore, free indirect discourse grammatically and mimetically intermediates between it and direct discourse, 
evoking a sense of combined direct and indirect discourse. This privileges the past tense and third-person references, which may be an intentional device used to complicate the capacity to differentiate a character's thoughts from the narrator's report, thus resulting in the semantic superpositioning of narrator and character. The Waste Land's adoption of free indirect discourse includes Marie, Madame Sosostris, the nervous woman who urges Lil and Tiresias, in addition to the nonhuman voices of the nightingale and the thunder. The first chapter of "The Burial of the Dead", begins with the surprising poetic value of strange connections, that is: "April is the cruellest month", "Winter kept us warm" and "Summer surprised us" (Eliot, 2005, p. 1344). The narration at the outset provides the narrator's personal perspective in the present tense, subsequently transitioning to the past tense through the adoption of the first personal plural, which is the ambiguous "Winter kept us warm." This marks the moment that generates the communication, which makes readers stop and consider, while listeners to the spoken "I" must continue accompanying the narrator. The character who states, "Winter kept us warm", is potentially not the same person who exclaims that, "Summer surprised us", although this narrative form effectively makes the character, narrator and the reader participate in the story and this part of the poem. Moreover, a shift of voice occurs from the beginning of the section providing Marie's narration. The reader experiences past glory as recalled in Marie's memory, thus feeling the paradox between life and death.

The pub scene in "A Game of Chess" is considered to provide a representation of female voices and sexual relationships. This part is characterised by an abundance of free indirect discourse, with it being challenging to identify the narrative's unity through the sudden swings between colloquial dialogue and the altering tense and lengthy sections of narration. Emery-Peck (2008) conveys how Eliot seeks to investigate the interrelationship between standard narrative methods and alternative forces through the production, circulation and comprehension of literary forms. Munganga (2017) argues that Eliot juxtaposes an urgent tone with sexual privilege, thus acting as a means by which to highlight women's objectification, which prevailed throughout this period. This is further emphasised during the unfolding narration between Lil and her unnamed counterpart. From the unnamed narrator's perspective, women must conform to their procreative role because, as the narrator states, there is nothing that women get married for if they do not want children. In fact, the entire pub scene is narrated by the storyteller "I", with a degree of transition in Lil's position. "HURRY UP PLEASE ITS TIME" was the publican's traditional announcement when British pubs had to close at 11 pm, although in this section, from the beginning to the end, it acts as a signal of both physical and spiritual death. When the narrator "I" shifts from the storyteller to Lil, the narration conveys a lower-class tone with ungrammatical sentences to attain the sense of distinctive voices: "I can't help it, she said, pulling a long face, / It's them pills I took, to bring it off, she said" (Eliot, 2005, p. 1348). Despite the unnamed voice repeatedly calling the urgency of closing time, the reader's attention is actually diverted to the transformation and exchange of the speaker-narrator, as opposed to the bar setting, which serves to increase the reader's participation. When the reader focuses on past events between the characters of Lil and Albert, the typical call "HURRY UP PLEASE ITS TIME" instantly interrupts the narration's succession, stressing the narrative's present action. Prior to the subsequent interruption made through the last call, Lil incrementally formulates her own position, realising what she needs to do. When the bar finally closes at the end of the section, the bidding of goodbye is juxtaposed with the echo of Ophelia's farewell before drowning in Hamlet. Lil's mental state reflects that of Ophelia's, with both Ophelia and Lil sharing the same fate; getting drowned in life. Ophelia died with her arms full of flowers, with the hyacinth girl holding the flower and the drowned Phoenician sailor being one. Eliot shifts the distance between the reader and the speaker, thus complicating the readers' position within the story, where they engage in Lil's inner monologue of her personal and emotional struggle, while witnessing the character and text's development.

\section{CONCLUSION}

The Waste Land displays a significant interest in exploring the paradoxical and mutually exclusive being forced into close proximity, by constructing changes in narrative style and voices in the story, characters and events. The poem's allusiveness resorts to history, traditions and canons, thus it draws strength and inspiration between the past and the present by revealing the repetition of modern people's lives. In the absence of central figures and images, this modernist poem provides greater space to adopt a narrative style. Exemplifying $20^{\text {th }}$ century modernism, The Waste Land's writing style powerfully reshaped conceptions of subjectivity, discourse and cultural hierarchy. Moreover, the poem represents Eliot's preliminary attempts to experiment with dramatic character shaping and openness to polyphony. Regardless of the multiplicity of narrative styles and voices, the poem retains a degree of unity, given that all incorporated voices merge into a sole personality. This modernist poem, devoid of central figures and images, provides greater scope to focus on narrative style. Therefore, armed with a more solid grasp of The Waste Land's narrative tensions, it is possible to establish that the poem's fragmentation is accentuated through juxtaposition.

\section{REFERENCES}

[1] Bruno, T. (2013). Buddhist Conceptual Rhyming and T. S. Eliot's Crisis of Connection in The Waste Land and "Burnt Norton". Asian Philosophy, 23(4), 365-378.

[2] Coyle, M. (2009). "Fishing, with the arid plain behind me": Difficulty, Deferral, and Form in The Waste Land. In D. E. Chinitz (Ed.), A Companion to T.S. Eliot. Malden, MA: Wiley-Blackwell, 157-167.

[3] Eliot, T. S. (2005). The Waste Land. In M. Ferguson, M. J. Salter \& J. Stallworthy (Eds.), The Norton Anthology of Poetry (5th 
edn.). New York: W.W. Norton, 1344-1356.

[4] Eliot, T. S. (no date). The Three Voices of Poetry. https://ishare.iask.sina.com.cn/f/11330300.html (accessed 29/5/2020).

[5] Emery-Peck \& J. Sorensen. (2008). Tom and Vivien Eliot Do Narrative in Different Voices: Mixing Genres in The Waste Land's Pub. Narrative, 16(3), 331-358.

[6] Fornero, C. (2005). Chess Is the Game Wherein I'LL Catch The Conscience of the King: The Metaphor of the Game of Chess in T. S. Eliot's The Waste Land. Yeats Eliot Review, 22(2), 2-6.

[7] Munganga, B. M. (2017). Narrated for the sake of it: Narration and its Modernist Consonance in T. S. Eliot's The Waste Land. Status Quaestionis, 13, 176-189.

[8] Penda, P. (2011). Cultural and Textual (Dis)unity: Poetics of Nothingness in The Waste Land. Humanities Commons, 133-145. http://dx.doi.org/10.17613/M6NC7G (accessed 13/6/2020).

[9] Pondrom, C. N. (2005). T. S. Eliot: The Performativity of Gender in The Waste Land. Modernism/ Modernity, 12(3), $425-441$.

[10] Rimmon-Kenan, S. (1983). Narrative Fiction: Contemporary Poetics. London: Routledge.

[11] Suarez, J. A. (2001). T. S. Eliot's The Waste Land, the gramophone, and the modernist discourse network. New Literary History, $32(3), 747-795$.

Feiyue Zhang is a postgraduate student of School of English Studies, Shanghai International Studies University. She currently researches in contemporary American and British literature. 